[Grudnoff, L., Hawe, E., \& Tuck, B. (2005). Effective Teaching and Standards for Teaching: A Loose Coupling. New Zealand Annual Review of Education, 14, 95-109]

\section{Effective Teaching and Standards for Teaching: A Loose Coupling}

\section{LEXIE GRUDNOFF, ELEANOR HAWE AND BRYAN TUCK}

\section{Abstract:}

Performance management with teacher appraisal has become mandatory in England and New Zealand. In England there is a single set of comprehensive standards that function as statutory requirements for initial teacher education and certification as a qualified teacher. In New Zealand we have programme requirements for initial teacher education that are not aligned with either the standards for registration or the standards in employment contracts. Moreover in New Zealand the standards are not legal requirements, e.g., when recommendations are being made for registration, the Teachers Council's standards are regarded as indicators of the factors that could be considered. The assumption seems to be that the more coherent and rigorous approach in England will be associated with more effective teaching. This article argues why this may not be the case, and calls for the involvement of teachers and researchers in the development of standards for teacher education and teaching, and the implementation of methods for evaluating teachers' practice.

$\mathrm{T}$ he New Zealand Ministry of Education identifies standards for teachers as a mechanism for improving the quality of teacher education, and by implication teaching (2004). Unfortunately, in 2004 , teachers are confronted with a variety of different statements of standards for teaching promulgated by a number of agencies. The Ministry of Education is not unaware of this confusion, and hopes that a comprehensive set of standards for teachers and teacher educators will be implemented and aligned by 2009 . The recent parliamentary inquiry into teacher education by the Education and Science Committee (2004) also saw as an urgent need the establishment of a unified set of standards. Such an outcome has been achieved in England, where teacher education, professional development within induction, and
96 Lexie Grudnoff, Eleanor Hawe and Bryan Tuck

registration are driven by a single comprehensive set of standards for teaching. Furthermore these standards are neither suggestions nor recommendations, but statutory requirements.

Associated with the implementation of a single set of statutory requirements in England is a greater prescription about what and how to teach and the external appraisal of teachers (Bartlett, 2000). One outcome of the Ministry of Education's objective of an aligned and comprehensive set of standards could be greater bureaucratic control over teachers' work in New Zealand. More often than not, public and political discussions about teacher quality and quality of teacher education programmes are embedded in a context of control and accountability (Yinger \& Hendricks-Lee, 2000). The current paper argues that the implementation in New Zealand of a coherent set of aligned standards and greater bureaucratic control over teachers' work is unlikely in itself to lead to an improvement in teaching or teacher education.

In England a single coherent set of standards plays a pivotal role in the path from initial teacher education to registration. Programmes within initial teacher education are aligned with these standards, which operate both as exit standards for graduation and as standards for teacher registration. A New Zealand teacher or teacher educator reading the publication Qualifying to Teach (Teacher Training Agency, 2003) would be surprised at the coherence and alignment of the standard statements across initial teacher education and registration in England. The statements are precise, statutory requirements, and the expectation is that they will be achieved on graduation from the initial teacher education provider.

There are no exit standards for initial teacher education in New Zealand, but rather "programme requirements", and these requirements are not aligned with the standards for registration. New Zealand has nothing equivalent to the short and full inspections of initial teacher education, carried out by the Office for Standards in Education (OfSTED) in England, and based on statutory requirements. Universities, colleges of education, polytechnics, private providers and wananga Maori in New Zealand would be more than somewhat surprised if review officers from the Education Review Office (ERO) arrived at regular intervals to undertake short and full inspections based on statutory requirements of theirinitial teacher education programmes. The standards for teacher registration in New Zealand are set out in the Teachers Council's definition of a "satisfactory teacher" (Ministry of 
Education \& Teachers Council, 2004, Appendix One). A principal is required to attest that a "provisionally registered" teacher has "been satisfactorily assessed against these Satisfactory Teacher dimensions" (p. 6). Unlike the standards in England, the dimensions of satisfactory teaching in New Zealand are not statutory requirements. Rather they are regarded as "indicator[s] of some of the factors that could be considered" (Appendix One). The situation in New Zealand is further compounded by the requirement that Boards of Trustees, as employers, implement another set of standards, Interim Professional Standards, for salary determinations, as part of their performance management systems. The picture is even more confused, as ERO in a recent report on the quality of Year 2 beginning teachers constructed its own framework of standards (Education Review Office, 2004). The standards terrain in New Zealand is thus contested by a number of independent agencies, and is confused, incoherent and fragmented. It is tempting to assume, that as a consequence, New Zealand students will experience a poorer standard of teaching than students in England. Is this in fact the case?

Thirty-one countries were involved in the Programme for International Student Assessment (PISA) (OECD, 2001). New Zealand fifteen year olds were ranked third in reading literacy and their counterparts in the United Kingdom were ranked seventh. The ranks for mathematical literacy were third and eighth respectively, and sixth and fourth respectively for scientific literacy. The results of the Progress in International Reading Literacy Study (PIRLS) (2001), do favour England over New Zealand at Year 5, a rank of third versus thirteenth out of 35 countries. These international comparisons must be interpreted with a degree of caution, because the samples are not directly comparable across the studies. However there is no clear trend for the achievement of students from New Zealand to suffer in comparison with students from England. The comparison with English students in PIRLS, although favouring English students, is hardly sufficient in itself to justify the expenditure of considerable resources on the development of a set of aligned and comprehensive statutory standards, and a system of centralised bureaucratic control over teachers' work

\section{Conceptual Confusions, Context and Consensus}

Why should we not be too surprised that a coherent, comprehensive and aligned set of teacher standards is not necessarily associated with better achievement? In part the explanation resides with the nature of the written statements of standards, which are overly generic and open (Miles, 1957), and thus able to spawn innumerable performance indicators. Many statements of standards appear to have been dredged from Scriven's "swamp of vagueness" (Scriven, 1996), and the water is made even murkier by the confusion between a standard manner of describing learning outcomes and standards as specifications of levels of performance (Elley, 1995; Tuck, 1994, 1995). As a way through the confusions and ambiguities, Sadler $(1987,1996)$ recommended we distinguish between "criteria" and "standards". Criteria describe the properties or characteristics of a desirable outcome, but do not specify a particular level of achievement to be attained, which is specified in a standard statement. This is a helpful distinction, and consistent with the notions of the National Academy of Education in The United States, which some time ago discriminated between "content standards" and "performance standards" (McClaughlin \& Shepard, 1995). Content standards are the broad and generic descriptions of knowledge and skills, whereas the performance standards are the operationalised definitions and concrete examples.

It is performance standards, in conjunction with an understanding of the content standards or criteria, which enable an assessor to distinguish between acceptable and unacceptable practice, and levels of practice. In New Zealand we often confuse content standards or criteria with performance standards. Moreover when agencies construct performance indicators, such as those used by ERO in the recent evaluation of the quality of beginning teachers, they are of such generality that they are best regarded as criteria or content standards. This failure to concretise content standards with aligned and valid performance standards, which have exemplars and scoring rubrics, is a major reason why statements about the characteristics of a "capable", "competent", or "satisfactory teacher" have such uneven impact on teaching practice.

It is relatively easy to reach consensus on criteria or content standards, because of their level of generality, but this is not the case with performance standards. Moss and Schultz (2001) provide a good example of the nature of the disagreements that can arise when one moves from content standards to performance standards. Although the case described occurred in the USA, the implications are universal. Nine judges, experienced teachers in the relevant curriculum area, were field testing performance standards developed by the Interstate New 
Teacher Assessment and Support Consortium (INTASC) to evaluate portfolios from beginning teachers in English and Language Arts. By this stage the judges should have had a shared understanding of what constituted evidence for good practice, given that many had been involved in developing the standards. However the judges could not reach consensus when scoring the portfolios, on the relative importance of a teacher providing models of good writing when teaching composition. The genesis of this conflict was apparent in neither the written statements of content standards nor the scoring rubrics. Rather it occurred because: (a) the process leading to the writing of content standards and the scoring rubrics was based on consensus, and this process appeared to marginalise dissenting voices; and (b) the content standards were generic in nature. To quote Moss and Schultz: "The consensus that is achieved and made available for public review is at a level of generality that rises above any differences in perspective that might have been reflected in teaching vignettes" (1989, p. 683). This example is sufficient to illustrate the considerable gap that exists between a content standard or criterion (Sadler, 1987) and the application of aligned performance standards in a particular context.

The movement from generic descriptions of content standards to the development of performance standards and their application in a particular context is, more often than not, poorly executed. There is however a strong case to be made for the involvement of practitioners in the process. The Centre for Teaching Excellence (1995, p. 3) believes that, "[I]t is difficult to overestimate the importance of teachers' professional judgements in the evaluation of practice: teachers' work occurs in response to complex and varied contexts." The implication is that it is wise to involve the practitioner in critical aspects of determining and setting standards in their context because of the contextual nature of teaching practice (Brown, 1996). Nutley, Davis, and Walter remind us that teaching is not alone in this respect, asserting that all professional practice is to some extent "contingent on both client needs and local context" $(2003$, p. 2$)$. This is of course not a justification for teachers rejecting collective standards-setting exercises, and leaves unanswered the nature of any community of practice (Grudnoff \& Tuck, 2003a). Rather it recognises that standards of performance are to some extent context dependent, and what constitutes appropriate evidence for good practice in a particular context is a matter of judgement. Ultimately if any evaluation of teachers' practice is to impact positively on teachers' understanding of their practice, then the teachers and the evaluators must be part of a community of interpreters (Wiliam, 1996), who share norms of practice and agree on what constitutes appropriate evidence of instances of good teaching in a particular context.

Consensus is a common strategy for developing and justifying a particular set of standards. However, as argued by Moss and Schultz (2001), consensus does have a downside, i.e., it can mask "dissensus", and can support a form of ideological hegemony, the privileging of the majority voice. The result can be that contentious issues are ignored, particularly if they are advocated by a minority voice. Moreover as Wolf (1996) suggests, it is unreasonable to assume that consensus actually exists or can be established in all instances. Tozer and Miretzky (2000) suggest that the process of consensus underlying the development of standards by the National Board for Professional Teacher Standards (NBPTS) to certify excellence in teaching may have created a systemic bias against particular urban "teaching styles". They imply that this bias could explain in part the low pass rates of teachers of coloured students. The National Board's certification panel, in an attempt to ensure that such biases were accounted for, involved a range of practitioners, curricular experts and scholars at every stage of the standards setting processes. However ensuring that key panels are representative of various stakeholders and "experts" is not in itself sufficient, as the process of consensus can mask "dissensus", and privilege the voice of a confident majority. If the notions of what constitutes teacher excellence are predicated on evidence of effects of practice on student learning then most of us are not going to be concerned. However if consensus in itself is the major justification for a set of standards then we need to be concerned.

\section{Appraisal for Accountability and Professional Learning}

The evaluation of teachers' practice has more than one purpose. For example, the official aims of teacher appraisal in the 1991 statutory requirements in England have two distinct purposes, the professional development and the management of teachers (Bartlett, 2000). Goddard and Emerson (1992) are not alone in believing that there is a tension between the two purposes. Kleinhenz and Ingvarson $(2004$, p. 31) argue, after reviewing a selection of systems in place to evaluate teaching, that improvements in teaching "will best be achieved when teachers and their organisations claim the responsibility for developing and implementing methods for assessing teacher performance." This position is consistent with the views of teachers in New Zealand, who 
considered collegiality and involvement in the appraisal process as a significant element in their professional development (Youngs \& Grootenboer, 2003). There appears to be reasonable support among New Zealand teachers for the view of Gunter (1996) that teachers are more likely to be conscious learners when they are involved in designing tasks within a negotiated framework. However the notion of employees as active participants in the development of criteria and processes for their appraisal is somewhat at odds with the notions of independence and objectivity valued by bureaucrats. As noted by Kleinhenz and Ingvarson (2004, p. 37) there can be "wide gaps between managerially designed procedures for appraisal and the realities of what teachers actually know and do." They regard the procedures used in the "Threshold" initiative to assess teaching excellence in England as a good example of such a gap. The "Threshold" initiative is not fundamentally concerned with observations of critical incidents in teaching; the teachers do not even submit videotapes, with reflective commentaries on vignettes of what they consider effective teaching. Rather they submit written material, followed by an interview with a head teacher, whose judgement is subject to external review. Not surprisingly the majority of teachers found the process somewhat negative, and few reported that the process led to positive changes in their practice. (Haynes, Wragg, Wragg, \& Chamberlin, 2001).

If the evaluation of teachers' practice against standards for teaching is to lead to positive changes in their practice then the focus must be on identifying needs for professional learning. Unfortunately, the evidence for the impact of professional learning on teachers' practice is not especially positive, especially when it emphasises a deficit in teachers' skills and understanding or is "one shot" in approach (Clarke \& Hollingworth, 2002). Contemporary writers argue that professional learning needs to be contextualised and embedded in the ongoing work of the teacher (Clarke \& Hollingworth, 2002; Feiman-Nemser, 2001). In support of this conclusion is the research by Langley (1997), who found that positive changes in teachers' practice are most likely when there is specific feedback on their practice in their everyday teaching context. The ongoing assessment and evaluation in successful professional learning is likely to be akin to the informal/interactive formative engagement, which Bell and Cowie (2001) and Harlen (1998) argue is the most productive for teaching and learning. Assessment in this model emphasises the role of the learner and is ongoing and seamless with instruction. The assessment and evaluation of teachers' practice for professional learning is also likely to be more productive when it is low stakes, and this is why the use of such information for salary determinations, promotions or competency decisions is problematic. Assessment and evaluation for these decisions is high stakes, which is hardly likely to encourage teachers to risk frankness (Moss \& Schultz, 1989) and to participate openly with colleagues in their ongoing professional learning.

\section{Standards and Effective Teaching}

There is a body of literature that identifies the types of interventions by teachers and the types of interactions between teachers and students that facilitate learning. Summaries of these productive interventions, which are grounded in research, can be found in meta analyses and best evidence syntheses (Brophy, 2001; Alton-Lee, 2003). Unfortunately the official statements of teacher standards in England and New Zealand have only a loose relationship with "research based understandings" of what makes a difference in teaching and learning (Hagger \& McIntyre, 2000). If information obtained from the current processes for appraising teachers satisfies the managers' and the public's need for making teachers accountable then so be it, but it is misguided to believe that this information can be used effectively to develop teachers' skills and understandings. This may seem self-evident, but it is only a year ago that Campbell, Kyriakides, Muijs and Robinson (2003) drew attention to the failure of current concepts of good teaching to explain differences in achievement among students at the level of the classroom. It seems as though proclamations of desirable standards of teaching and the characteristics of good teaching practice are not constrained by research evidence on what makes a difference with students. Hagger and McIntyre (2000) were encouraged by the support of the then Department of Education and Employment in England for the development of centres for the dissemination of evidence-based practice. This development has a parallel in New Zealand, where the Ministry of Education has begun to disseminate syntheses of best evidence practice (e.g., Alton-Lee, 2003). The outcome of such developments could be a shared understanding among teachers of what constitutes best evidence-based practice (Nutley et al., 2003) in a particular context. Unfortunately in the absence of such a development, the relationship between research understandings of what makes a difference in teaching and learning and the criteria for a "satisfactory teacher" remains problematic. 


\section{Conclusions}

Teachers do make a difference! (Hattie, 2003). The percentage of variance in students' achievement attributable to teachers differs from study to study, but what is undeniable is that "what happens in classrooms through quality teaching and the quality of the learning environment generated by the teachers and the students is the key variable to explaining up to $59 \%$, or even more, of the variance in student scores" (Alton-Lee, 2003, p 2). However it is naïve and misguided to believe that the development of a comprehensive aligned set of standards for teaching, as proposed by the Ministry of Education (2004), will create excellent teachers and solve the problems of dysfunctional schools and ineffective teaching (Darling-Hammond, 1999). Standards of conduct and performance are at the heart of every profession, and enable practitioners to be held accountable and ensure that programmes of professional education provide a reasonably common body of knowledge and skills (Darling-Hammond, 2000). However, if standards for teaching are to have a positive impact on teachers and students, then they must be embedded within a culture committed to professional learning, and the focus must be on the teachers themselves identifying their needs for professional learning (Ingvarson, 2003). ${ }^{1}$ This involvement can be educative in itself. For example, Gilmore found that teachers involved as administrators or markers in the National Education Monitoring Project (NEMP) developed "ideas about assessment that they could apply meaningfully in their classroom or school" (2001), and teachers involved in similar activities in the certification programme of NBPTS in America, probably the most systematic attempt to identify the elements of good teaching and to credential excellent teachers, also believed that the process impacted positively on their teaching and student learning. Unfortunately the achievement of students taught by certified NBPTS teachers is not always significantly better than that of students taught by non-certified teachers (Bond, Smith, Baker, \& Hattie, 2000). Given the hundreds of millions of dollars invested in the certification programme, this must be disappointing. Irrespective of this disappointment, the involvement of teachers in the evaluation of their practice will, at the very least, go some way towards ensuring the creation of a community of practitioners who have a shared understanding of what standards for teaching and professional learning mean in practice.
It is time for a dialogue between the various agencies promulgating standards for teaching, on the one hand, and teachers, teacher educators, and those involved in constructing relevant meta analyses and best evidence syntheses, on the other. ${ }^{2}$ Those involved in meta analyses and best evidence syntheses can inform the agencies on what makes a difference in teaching and learning, and, teachers and teacher educators are more likely to be conscious learners when they are involved in both the construction of standards and implementing methods for evaluating their practice within a negotiated framework. It would also be inappropriate to assume that a common set of standards across initial teacher education and registration is in fact desirable. There may be good reasons for having aligned but different exit standards for teacher education and teacher registration as learning about teaching during initial teacher education is necessarily different from learning while teaching during the period of supervised induction (Grudnoff \& Tuck, 2003b). Any standards for teaching must make a clear distinction between content standards and performance standards or between criteria and standards, and the latter must be aligned validly with the former. Consensus will inevitably be used when developing standards for teaching, but the participants cannot afford to be too enamoured of its charms, because of the hooks involved. Standards for teaching and research-based understandings of what makes a difference in teaching are at present too loosely coupled (Weick, 1976). There needs to be a much tighter alignment if standards for teaching are to have a positive influence on teaching and learning.

Notes

1. There is a considerable literature on what works and does not work in professional development and professional learning. Ingvarson (2003) provides a contemporary overview, with a section on the role of teaching standards in professional learning. This is particularly relevant for New Zealand, given the stage we have reached in the development of standards for teaching.

2. The focus of this paper on the role that meta analyses and best evidence syntheses have in the development of standards for teaching ignores the ethical and political dimensions of teaching. As Snook (2003, p. 39) comments, "teaching involves "balancing respect for autonomy and reason against initiating children into the values of society, including pluralism, democracy and justice." As authors, we recognise the critical nature of the ethical and political dimensions, but disclaim the expertise to do them justice. 


\section{References}

Alton-Lee, A. (2003). Quality teaching for diverse students in schooling: Best evidence synthesis. Wellington: Ministry of Education.

Bartlett, S. (2000). The development of teacher appraisal: A recent history. British Journal of Educational Studies, 48, 24-33.

Bell, B., \& Cowie, B. (2001). Formative assessment and science education. London: Kluwer Academic Publishers.

Bond, L., Smith, T., Baker, W., \& Hattie, J. (2000). The certification system of the National Board for Professional Teaching Standards: A construct and consequential validity study. Greensboro: University of North Carolina at Greensboro, Centre for Educational Research and Evaluation.

Brophy, J. (Ed.). (2001). Subject-specific instructional methods and activities. In Advances in Research on Teaching, Vol. 8. New York: Elsevier.

Brown, S. (1996). Assessing student teachers: The implications of "competence" and "school-based" models. Keynote address at New Zealand Council for Teacher Education Biennial Conference, Dunedin, New Zealand.

Campbell, R. J., Kyriakides, L., Muijs, R. D., \& Robinson, W. (2003). Differential teacher effectiveness: Towards a model for research and teacher appraisal. Oxford Review of Education, 29, 347-362.

Centre for Teaching Excellence. (1995). Standards framework for teachers: Draft for consultation. Brisbane: Education Queensland.

Clarke, D., \& Hollingworth, H. (2002). Elaborating a model of teacher professional growth. Teaching and Teacher Education, 18, 947-968.

Darling-Hammond, L. (1999). Reshaping teaching policy, preparation and practice: Influences of the National Board for Professional Teaching Standards. Washington, DC: AACTE Publications.

Darling-Hammond, L. (2000). Reforming teacher preparation and licensing: Debating the evidence. Teachers College Record, 102, 28-57.

Education Review Office. (2004). The quality of Year 2 beginning teachers. Wellington: Education Review Office.

Education and Science Committee. (2004). Inquiry into teacher education. Report of the Education and Science Committee. Wellington: House of Representatives.
Elley, W. (1995). What is wrong with standards based assessment? In R. Peddie \& B. Tuck (Eds.), Setting the standards: Issues in assessment for national qualifications (pp. 78-98). Palmerston North: Dunmore Press.

Feiman-Nemser, S. (2001). From preparation to practice: Designing a continuum to strengthen and sustain teaching. Teachers College Record, 103, 1013-1056.

Gilmore, A. (2001). NEMP experiences: Teachers talk about lessons learned and changes in their assessment practices. set: Research Information for Teachers, 3, 11-15.

Goddard, I., \& Emerson, C. (1992). Appraisal and your school. Oxford: Heinemann.

Gunter, H. (1996). Appraisal and the school as a learning organisation. School Organisation, 16, 89-100.

Grudnoff, L., \& Tuck, B. (2003a). Professional standards and the professional development of beginning teachers. Paper presented at the Annual Conference of ICET, Melbourne, Australia.

Grudnoff, L., \& Tuck, B. (2003b). Learning about teaching, learning while teaching, and becoming a teacher. English Teaching: Practice and Critique, 2, 33-42.

Hagger, H., \& McIntyre, D. (2000). What can research tell us about teacher education. Oxford Review of Education, 26, 483-496.

Hattie, J. (2003). Teachers make a difference: What is the research evidence? Interpretations, 36, 27-38.

Haynes, G. S., Wragg, E. C., Wragg, C. M., \& Chamberlin, R. P. (2001). Threshold Assessment: The experiences and views of teachers. Paper presented at the Annual Conference of BERA, Leeds.

Ingvarson, L. (2003). Building a learning profession. ACER Policy Briefs. Camberwell, Victoria: Australian Council for Educational Research.

Kleinhenz, E., \& Ingvarson, L. (2004). Teacher accountability in Australia: Current policies and practices and their relation to the improvement of teaching and learning. Research Papers in Education, 19, 31-49.

Langley, J. (1997). The development of an inservice training programme to enable kindergarten teachers to better manage the behaviour of young children with behavioural disorders. Unpublished $\mathrm{PhD}$ thesis, University of Canterbury, Christchurch, New Zealand. 
McClaughlin, M., \& Sheppard, L. (1995). Improving education through standards based reform: A report of the National Academy of Education panel on standards-based educational reform. Stanford: National Academy of Education.

Miles, T. R. (1957). On defining intelligence. British Journal of Educational Psychology, 27, 153-165.

Ministry of Education. (2004). A strategy for preparing teacher education graduates to teach diverse learners effectively: Draft for consultation. Wellington: Ministry of Education.

Ministry of Education \& New Zealand Teachers Council. (2004). Towards full registration: A support kit for schools. Wellington: Ministry of Education.

Moss, P., \& Schultz, A. (1989). Risking frankness in educational achievement. Phi Delta Kappan, 80, 680-687.

Moss, P., \& Schultz, A. (2001). Educational standards and the search for consensus. American Educational Research Journal, 38, 37-70.

Muijs, D., \& Reynolds, D. (2001) Effective teaching: Evidence and practice. London: Paul Chapman Publishing.

Nutley, S., Davies, H., \& Walter, I. (2003). Evidence based policy and practice: Cross sector lessons in the UK. Keynote paper for the Social Policy Research and Evaluation Conference, Wellington, New Zealand.

Organisation for Economic Cooperation and Development (OECD). (2001). Knowledge and skills for life. First results from PISA 2000. Programme for International Student Assessment. Paris: OECD. $<$ www.SourceOECD.org >

Progress in International Reading Literacy Study. (2001). Final results from the Progress in International Reading Literacy Study (PIRLS) and the repeat of the 1990-1991 Reading Literacy Study (10-Year Trends Study) for Year 5 students. Wellington: Ministry of Education, Research Division.

Sadler, R. (1987). Specifying and promulgating achievement standards. Oxford Review of Education, 13, 191-209.

Sadler, R. (1996). Criteria and standards in student assessment. Paper presented at the Annual Conference of HERDSA, Perth, Australia.

Scriven, M. (1996). Assessment in teacher education: Getting clear on the concept. Teaching $\mathcal{E}$ Teacher Education, 12, 443-450.
Snook, I. (2003). The ethical teacher. Palmerston North: Dunmore Press.

Teacher Training Agency. (2003). Qualifying to teach: Professional standards for qualified teacher status and requirements for initial teacher training. London: Teacher Training Agency.

Tozer, S., \& Miretzky, D. (2000). Professional teaching standards and the social foundations of education. Educational Studies, 31(2), 106-120.

Tuck, B. (1994). Fine, but occasionally overcast with the possibility of thunder and lightning: A year in the life of the New Zealand Qualifications Authority. New Zealand Annual Review of Education, 4, 229-245.

Tuck, B. (1995). A plea for moderation. In R. Peddie and B. Tuck (Eds.), Setting the standards: Issues in assessment for national qualifications (pp. 59-77). Palmerston North: Dunmore Press.

Weick, K. E. (1976). Educational organisations as loosely coupled systems. Administrative Science Quarterly, 21, 1-110.

Wiliam, D. (1996). Meanings and consequences in standards setting. Assessment in Education, 3, 287-307.

Wolf, A. (1996). Setting standards in educational assessment: Basis for consensus? Focus for dissent? Keynote address at the First Assessment and Evaluation Research Unit Conference, University of Queensland, Brisbane, Australia. ISBN 0867767138.

Yinger, R. \& Hendricks-Lee, M. (2000). The language of standards and teacher education reform. Education Policy, 14, 94-107.

Youngs, H., \& Grootenboer, R. (2003). Primary and secondary teachers' perceptions of their appraisal: Implications for school leaders. New Zealand Journal of Educational Leadership, 18, 77-90.

\section{The authors}

Lexie Grudnoff is the Head of Teacher Education, Faculty of Education, Epsom Campus, The University of Auckland. Her research interests are initial teacher education and the professional development of beginning teachers, and she is currently following a cohort of beginning teachers, identifying institutional, personal and familial correlates of their development as teachers. Recent publications address sources of stress and satisfaction among beginning teachers, learning about teaching during initial teacher education and learning while teaching, and the transition from novice to "savvy" teacher. 
Eleanor Hawe is a Principal Lecturer in Postgraduate Studies and Research, Faculty of Education, Epsom Campus, The University of Auckland. She writes and teaches in the areas of assessment, teaching and learning. Recent publications include the rhetoric and practice of standards based assessment in a tertiary institution, the reluctance to award failing grades in tertiary education, and teachers' perceptions of the value of standardised school entry assessments.

Bryan Tuck is a Reader in Teacher Education, Faculty of Education, Epsom Campus, The University of Auckland. His research interests are assessment and evaluation and the adjustment of beginning teachers.

Recent publications addresses issues in standards and teacher education, the transition from beginning to "savvy" teacher, learning about teaching during initial teacher education and learning while teaching, sources of stress and satisfaction in primary teachers, the relationship between stress and satisfaction in beginning teachers, and attentiveness and achievement in primary pupils. 